
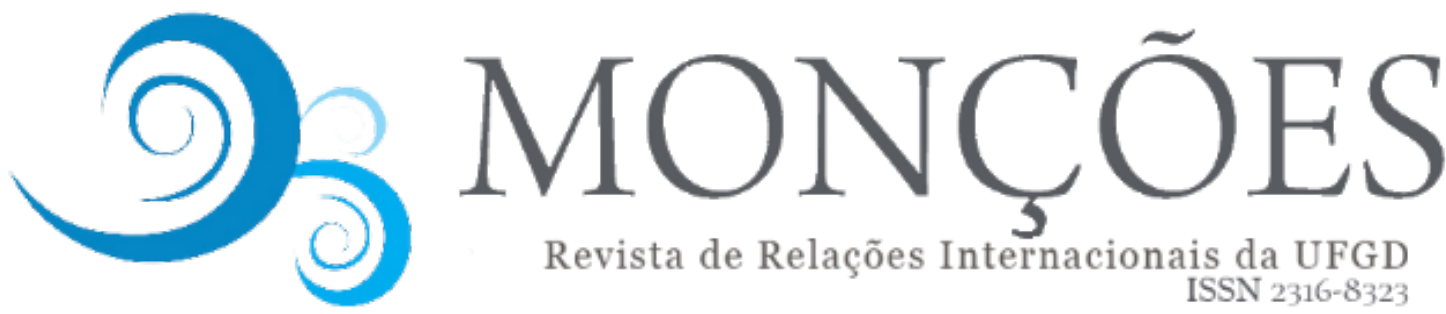

ISSN 2316-8323

\title{
ULTRA AEQUINOXIALEM NON PECCARI: ANARQUIA, ESTADO DE NATUREZA E A CONSTRUÇÃO DA ORDEM POLÍTICO-ESPACIAL
}

\author{
ONOFRE DOS SANTOS FILHO \\ Sociólogo, professor do Departamento de Relações Internacionais da Pontifícia \\ Universidade Católica de Minas Gerais.
}

\begin{abstract}
RESUMO: A máxima do século XVI, ultra aequinoxialem non peccari - ao sul da linha equinocial não se peca -, expressa mais do que uma divisão entre vício no Sul e virtude no Norte. Exprime um sistema de localização espacial que, a partir do Trópico de Câncer, demarca dois mundos: um ao Norte, baseado no Direito das Gentes europeu que regula o exercício da violência e as relações entre os nascentes Estados territoriais; outro ao Sul, não sujeito a este Direito, aberto ao exercício da violência pelos Estados europeus na tomada de terra do Novo Mundo. Processo de domínio que mais tarde os contratualistas racionalizarão através de nova clivagem: sociedades não contratuais ao sul do Trópico de Câncer; sociedades contratuais ao norte do Trópico de Câncer. Isso resultou no entendimento dos povos do Sul vivendo em situação de anarquia no estado de natureza, o que autorizou o recurso à força pelos colonizadores, legitimando a construção de um novo ordenamento social. Tendo em vista este processo, o propósito deste ensaio é o de analisar a extensão da ideia de anarquia e de estado de natureza às interações internacionais e suas implicações para a interpretação do internacional a partir das relações Sul-Norte.
\end{abstract}

PALAVRAS-CHAVE: anarquia, estado de natureza, espacialidade.

\section{ULTRA AEQUINOXIALEM NON PECCARI: ANARCHY, STATE OF NATURE AND THE CONSTRUCTION OF THE SPACE POLITICAL ORDER ${ }^{1}$}

\begin{abstract}
The 16th Century saying ultra aequinoxialem non peccari - there is no sin below the equator - shows more than a difference between a South, the place of vice, and a virtuous North. It expresses a spatial location system that, using the Tropic of Cancer, delimits two worlds: one on the North, ruled by the European Law of Nations that orders the use of violence and regulates the relations between territorial States; the other one on the South, where these rules do not apply, and where violence could be used by European States as they stormed the New World. Later on, such domination process would be justified by the theorists of social contract using a different cleavage: non-contractual societies inhabiting the South of the Tropic of Cancer; contractual societies living on its North. This produced an understanding that Southern people lived in an anarchical situation, corresponding to their state of nature, which authorized colonizers to enforce a new social order by violent means. Taking this process into account, this essay aims to analyze the extend of both anarchy and state of nature ideas to international relations, and by these means to understand the consequences of South-North relations on defining the idea of international.
\end{abstract}

\footnotetext{
${ }^{1}$ Este ensaio reproduz, direta ou indiretamente, parte das reflexões desenvolvidas em tese de doutoramento, ainda não defendida, no Programa de Pós-graduação em Geografia - ênfase no tratamento da informação espacial - da PUC Minas, sob a orientação do prof. Dr. João Francisco de Abreu e a co-orientação do prof. Dr. Oswaldo Bueno Amorim Filho.
}

Monções: Revista de Relações Internacionais da UFGD, Dourados, v.8. n.15, jan./jun. Disponível em: http://ojs.ufgd.edu.br/index.php/moncoes 
KEYWORDS: anarchy, state of nature, spatiality

\section{Introdução}

A máxima do século $\mathrm{XVI}$, ultra aequinoxialem non peccari - ao sul da linha equinocial não se peca -, expressa mais do que uma divisão entre vício no Sul e virtude no Norte. Exprime um sistema de localização espacial que, a partir do Trópico de Câncer, demarca dois mundos distintos: um ao Norte, baseado no Direito das Gentes europeu que regula o exercício da violência e as relações entre os nascentes Estados territoriais; outro ao Sul, não sujeito a este Direito, aberto ao exercício da violência pelos Estados europeus na tomada de terra do Novo Mundo.

Trata-se de um processo de domínio que mais tarde os contratualistas racionalizarão através de nova clivagem: sociedades não contratuais ao sul do Trópico de Câncer; sociedades contratuais ao norte do Trópico de Câncer. Essa nova clivagem resultou no entendimento dos povos do Sul vivendo em situação de anarquia no estado de natureza. Como em tal situação a única forma de ordenamento possível é aquela derivada do uso da força, os Estados colonizadores europeus se viram autorizados a ela recorrerem na conquista e dominação das etnias locais do chamado Novo Mundo. Após o último empreendimento colonial europeu no último quartel do século XIX, conhecido como a partilha da África, não havia mais terras livres a conquistar e a ideia de anarquia e de estado de natureza foi paulatinamente se estendendo ao conjunto das interações internacionais.

$\mathrm{Na}$ medida em que se consolidava academicamente, as Relações Internacionais assimilaram essa percepção no entendimento dos fenômenos internacionais. Acreditamos, contudo, que se trata de uma narrativa que confere sentido a uma ordem político-espacial que consagra as relações de desigualdade entre o Norte e o Sul. O propósito deste ensaio é, assim, o de analisar as implicações 
dessa narrativa para a interpretação do internacional a partir das relações Sul-Norte e do lugar que o primeiro ocupa em suas interações com o segundo.

\section{Estado de natureza, política e vida civilizada}

A ideia do estado de natureza e de contrato não expressa apenas um pressuposto para se entender a constituição do Estado como emulação de povos hipoteticamente livres. Esses dois elementos assinalam um divisor de águas entre uma vida aparentemente sem ordem e outra em que um ordenamento social regula a vida de coletividades dificultando, ou até mesmo impedindo, que retornem a uma vida de egoísmo absoluto. Assim, eles assinalam o nascimento de uma vida civilizada em que o recurso à força se torna prerrogativa de uma instituição política central, a que os indivíduos se submetem pelo pacto, e que por meio dele renunciam ao uso da violência para a consecução de seus objetivos e a realização de seus interesses. Isso significa que uma vida civilizada pressupõe que os homens se comprometam a resolver suas diferenças por recursos outros que não a força, situação em que a política passa a ter um papel fundamental na solução das controvérsias humanas ${ }^{2}$.

A ideia de vida civilizada depende de como se concebe a anarquia no estado de natureza e o contrato dela resultante. Em Hobbes (1983), a anarquia decorre da ausência de uma autoridade central e na medida em o que pacto concebe o Leviatã como garantidor da segurança de todos, ele se torna o agente por excelência da vida civilizada. Na proporção em que coíbe os homens retornarem à luta de todos contra todos - até mesmo autorizando o uso da força pelo poder central - ele assegura a

\footnotetext{
${ }^{2} \mathrm{O}$ contratualismo não se reduz a Hobbes e a Locke. Vamos nos ater a estes dois autores devido à centralidade de suas concepções de anarquia e de estado de natureza para as análises predominantes em Relações Internacionais. Nossa preocupação não é a de discutir estas concepções em vista da constituição do Estado moderno, mas de tomá-las como recurso heurístico para a emergência de uma nova espacialidade que organiza espacial e politicamente povos contratuais / civilizados ao Norte notadamente a Europa ocidental - e povos não contratuais / incivilizados ao Sul, tendo como referência a tomada de terra nos termos schmittianos. Portanto, iremos desconsiderar a discussão de anarquia e de estado de natureza no que se refere à dinâmica interna da vida europeia e nos voltarmos para as suas implicações na constituição de uma ordem político-espacial que situa desigualmente povos ao norte e ao sul do equador e suas consequências para o entendimento dos fenômenos internacionais.
} 
solução de controvérsias por meio das regras criadas pelo próprio Estado, principalmente aquelas que regulam o meum e o tuum - o meu e o teu.

Em contraposição a Hobbes, para Locke (1983), os homens vivem no estado de natureza em igualdade e liberdade naturais, inclusive lhes sendo assegurado o direito à propriedade. Contudo, tanto o direito à liberdade, a igualdade e a propriedade estariam ameaçados pela tendência humana a utilizá-los em benefício próprio ou daqueles que lhes são próximos. Frente a isso, os homens teriam renunciado ao estado natural em benefício da sociedade política em que livremente acordam entre si a maneira como seriam governados, e não entre súditos e o soberano como advoga Hobbes. O pacto reafirma os direitos naturais iniciais, e a sua característica marcante é que os homens se recusam a exercê-los individualmente, mas de forma coletiva. Assim, em Locke a sociedade política garante a vida civilizada na medida em que ela reafirma os direitos naturais, e oferece uma via para a solução das controvérsias humanas por meio do governo representativo.

Do contrato social irão emergir concepções diferentes da soberania e, por implicação, da política. Em Hobbes (1983), como ele nega aos sujeitos ao pacto a possibilidade de recorrer à força contra o poder soberano, a soberania assenta-se, em última instância, na exclusividade do exercício da força. No limite o poder soberano pode recorrer à violência para a manutenção do pacto e punir aqueles que contra ele se levantarem. Ainda que o Estado se constitua a partir da decisão dos contratantes, uma vez concordado com o pacto, a soberania é prerrogativa do Estado que não pode mais Ihe ser subtraída. O governo se torna, então, uma afirmação constante do poder soberano e o seu exercício a manutenção desse poder. A política se manifesta, à maneira weberiana, como conquista e manutenção do poder necessários à garantia da vida civilizada, no sentido de se impedir o retorno ao estado de natureza e à violência generalizada de todos contra todos.

Em Locke (1983), como o contrato é constituído entre homens livres para a manutenção dos direitos naturais, a pactuação implica, também, na escolha da forma de governo que melhor preserve esses direitos. Do contrato emergiria a sociedade política em que as leis, produto do consentimento dos contratantes e aplicadas por magistrados imparciais, garantiriam um estado de não violência social. O Estado é 
constituído para preservar o acordado, daí a política como governo representativo ser a melhor expressão do contrato do qual se origina o Estado. Nessa perspectiva, a soberania é emanação da própria assembleia de homens livres, e não uma prerrogativa irremovível do Estado como no caso hobbesiano. O Estado deve preservar o que foi acordado, e na medida em que ele não corresponder àquilo que os contratantes dispuseram acerca da preservação dos direitos naturais, os segundos podem contra o primeiro se levantar e destituí-lo das prerrogativas de soberania. A vida civilizada, aqui, também é a possibilidade de se viver de forma harmoniosa, o que é possível pela representação política, mas ao contrário de Hobbes, o recurso à força pelo Estado é limitado pelo seu compromisso de garantir os direitos naturais. $\mathrm{Na}$ medida em que ele assim não o fizer, suas prerrogativas de soberania poderão lhe ser subtraídas e os contratantes constituírem novo governo que atenda ao estabelecido no pacto.

Schmitt (2014) pressupõe que o direito público europeu constrói a estatalidade por meio dos acordos compartilhados entre os príncipes europeus em suas interações extraterritoriais, mas, no nosso entendimento, isso só é possível se do ponto de vista doméstico a ideia de um contrato entre governantes e governados (HOBBES, 1983) ou constituído livremente entre os governados (LOCKE, 1983) seja hipoteticamente estabelecida. Como na ideia de contrato, tanto em Hobbes como em Locke, se pressupõem os direitos de propriedade, isto significa, em termos schmittianos, que a garantia da propriedade reconhece a procedência da tomada de terra no âmbito doméstico sobre o externo. Assegurado esse direito é possível falar de uma tomada de terra - apropriação e domínio de porções da superfície terrestre -, legitimada domesticamente pelo contrato, se projetando do interior para o exterior em direção a terras livres ou sob o domínio reconhecido de outro senhor. É na dialética estabelecida entre o direito de propriedade autorizada pelo contrato no domínio doméstico e a prerrogativa de tomada de terra no plano externo pelo direito público europeu que um novo nomos da terra, no entendimento schmittiano, se constitui e produz um novo ordenamento e localização do ponto de vista dos grandes espaços globais ${ }^{3}$.

\footnotetext{
${ }^{3}$ A dialética entre interno e externo é essencial para o entendimento das ideias de Schmitt. É a tomada de terra do ponto de vista doméstico que permite a territorialização nos termos requeridos pelo Estado
} 
A estatalidade expressa, assim, duas espacialidades: a) a espacialidade das sociedades contratuais representada por aquelas coletividades em que o ordenamento social é produto de um pacto entre os indivíduos que constituem o Estado soberano; b) a espacialidade das sociedades não contratuais em que o ordenamento social não pressupõe o pacto e o ordenamento social não resulta nos Estados territoriais. Na linha de raciocínio dos autores citados, as primeiras se reduzem histórica e espacialmente ao contexto europeu, especificamente a Europa ocidental, e as segundas ao espaço não europeu. O direito público europeu é produto das sociedades contratuais, o que significa que ele regula as relações interestatais daqueles Estados tidos como decisões de coletividades que assim os constituíram livremente como poderes soberanos. Schmitt (2014) afirma que o direito público europeu, antes restrito às relações interestatais, se expande para além de seus limites espaciais, isto é, para as sociedades não contratuais, e assim passa a se constituir em um novo nomos da Terra. O equacionamento dessa questão implica entender o que são as sociedades não contratuais, o que nos remete, por sua vez, ao entendimento da concretude ou não do estado de natureza.

\section{Estado de natureza, anarquia, contrato e a clivagem espacial do mundo}

Referindo-se ao estado deplorável em que vivem os homens no estado de natureza, Hobbes (1983) discorre sobre os perigos de se viver sob a ameaça constante da guerra. Todos os confortos para o bem-estar humano não podem florescer nessa situação, pois "[...] não há conhecimento da face da Terra, nem cômputo do tempo, nem artes, nem letras; não há sociedade; e o que é pior do que

moderno e, também, seu entendimento da política como designação de amigo / inimigo pelo agente soberano (SCHMITT, 2008), tanto do ponto de vista interno como externo. A projeção externa, expressa na tomada de terras livres, permite a constituição dos grandes espaços globais (SCHMITT, 2014) e suas clivagens Norte e Sul, oriundas da colonização, e mais tarde, com a projeção internacional estadunidense, aquela constituída pelo Hemisfério Ocidental e o Hemisfério Oriental. Em sua leitura da política Schmitt se contrapõe, tendo em vista o contratualismo anglosaxão, tanto ao romantismo, ao liberalismo individualista e ao normativismo positivista da passagem do século XIX para o século XX que para o autor dificultavam a compreensão dos fundamentos da autoridade e da vida pública, em especial o entendimento efetivo da política e da natureza do poder estatal. Para uma boa introdução as ideias de Schmitt vide: VILLACAÑAS, 2008; MORAIS e COUTINHO, 2014. 
tudo, um constante temor e perigo de morte violenta". Assim, a vida "[...] é solitária, pobre, sórdida, embrutecida e curta" (HOBBES, 1983, p. 76). Continua o raciocínio argumentando sobre a vida sem proteção para, depois, concluir.

Poderá porventura pensar-se que nunca existiu um tal tempo, nem uma condição de guerra como esta, e acredito que jamais tenha sido geralmente assim, no mundo inteiro; mas há muitos lugares onde atualmente se vive assim. Porque os povos selvagens de muitos lugares da América, com exceção do governo de pequenas famílias, cuja concórdia depende da concupiscência natural, não possuem qualquer espécie de governo, e vivem em nossos dias daquela maneira embrutecida que acima referi. Seja como for, é fácil conceber qual seria o gênero de vida quando não havia poder comum a recear, através do gênero de vida em que os homens que anteriormente viveram sob um governo pacífico costumam deixar-se cair, numa guerra civil (HOBBES, 1983, p. 76).

Ainda que o estado de natureza possa ser concebido como metáfora ao referirse às sociedades europeias, aqui, no que se refere ao Novo Mundo, ele é pensado como uma situação de fato. Os povos selvagens da América vivem sem governo, a não ser aquele de natureza familiar, e vivem da forma embrutecida da maneira que Hobbes descreve o estado de natureza. Viver sem um governo, na acepção hobbesiana, é viver sem uma autoridade central constituída pelo contrato, o que significa, então, que os povos selvagens da América estão em situação de anarquia, portanto constituem sociedades não contratuais. Identificam-se, assim, as sociedades não contratuais como sociedades anárquicas vivendo em seu estado natural. Se o direito das gentes se aplica às sociedades contratuais e delas ele se projeta para o restante do mundo conhecido, qual é o status das sociedades não contratuais em sua expansão?

Esse problema já se colocara desde o início das Navegações e suas descobertas. A expansão e a colonização lusitana são entendidas, desde o início, como conquista e missão catequético-civilizadora. Como conquista, ela é empreendida como ato de força em que a submissão do vencido e a apropriação de seus despojos são tributos ao guerreiro em campo de batalha. Como catequesecivilizacional, é apropriação do vencido a partir da reelaboração do seu 
universo simbólico: alguns valores são excluídos e outros incluídos, numa lógica de aculturação que pode implicar, ou não, no uso da força. Mas o fundamental na catequese é a persuasão via recursos da oratória / retórica. Digamos que a conquista é ato da espada; a catequese-civilizadora é, acima de tudo, função da palavra (SANTOS FILHO, 1983).

Ao mesmo tempo, se constrói um vasto campo de conhecimento sintetizado naquilo que podemos denominar Antropologia/Geografia colonial (BARRETO, 1987). Constituído de diversos relatos sobre as diferentes sociedades descobertas, esse campo está eivado de juízos valorativos que, frente à pluralidade cultural do mundo, são discutidos e rediscutidos. Porém, os dados dos viajantes ultrapassam a simples informação, funcionando como elementos de interpretação/reinterpretação de "[...] alguns dos conceitos-chave da racionalidade antropológica (natureza humana, civilização, diferença), vencendo ou sendo vencidos pelos numerosos obstáculos etnocêntricos que educam o olhar e o pensar do homem do século XVI" (BARRETO, 1987 , p.35). Nesse contexto, ao pousar nesta nova realidade, o olhar colonizador espanta-se diante do outro e daquilo que lhe oferece na sua diversidade. Diversidade essa que o obriga a repensar suas ideias, a tentar vencer o diferente pela destruição da cultura que contempla ao mesmo tempo em que incorpora muitos de seus elementos simbólicos (SANTOS FILHO, 1993).

No âmbito do conhecimento acumulado pela Antropologia/Geografia Colonial irão se expressar duas forças, a Coroa e a Igreja Romana, no intuito de se produzir um novo sentido para terras recém-descobertas e seus habitantes. Enquanto a Coroa entende os descobrimentos como atos de conquista, a Igreja Romana a entende como um projeto de evangelização de novos fiéis para o Catolicismo. Antagônicos, mas ao mesmo tempo complementares, os dois projetos da conquista colonial vão render longas polêmicas, como aquelas de Bartoloméo de las Casas com a Coroa espanhola ou os conflitos dos jesuítas no Brasil acerca da escravização de indígenas, ou ainda os esforços de Vitória para interpretar o Novo Mundo a partir da Escolástica renovada etc. Mas o importante a assinalar é que desse processo emerge a primeira classificação dos povos selvagens das Américas frente aos seus descobridores europeus: os segundos são cristãos, os primeiros selvagens pagãos. 
Independentemente dos projetos da Coroa e da Igreja Romana o problema era catequizá-los para sua integração à civilização da cristandade, seja como bons súditos do rei ou como fiéis católicos obedientes ao papa.

Os conflitos entre os reinos de Portugal e Espanha pelo domínio das novas terras descobertas resultaram em um apelo à mediação do papa Alexandre VI em 1493. O papa estabeleceu uma linha demarcatória, uma raya, que se estendia longitudinalmente 100 léguas (cerca de 885 quilômetros) a oeste de Cabo Verde: os portugueses deveriam manter suas expedições a leste dessa linha e os espanhóis a oeste, e as terras descobertas no âmbito desse marco constituiriam domínio dos respectivos reinos. O acordo, no entanto, não foi bem visto por Portugal e os demais Estados marítimos europeus - França, Inglaterra e Países Baixos - não aceitaram a mediação papal, como também recusavam qualquer interferência pontifícia em assuntos relativos à conquista do Novo Mundo. A situação resultou em um novo acordo entre espanhóis e portugueses (1494), o Tratado de Tordesilhas, que deslocou a linha demarcatória para 370 léguas (cerca de 1.900 quilômetros) a oeste de Cabo Verde, garantindo-se a posse das terras a leste aos portugueses e a oeste aos espanhóis.

À raya é peculiar o fato de que os dois príncipes reconhecem a mesma autoridade espiritual, inclusive do ponto de vista do direito das gentes, e firmam um acordo sobre a aquisição de terras de príncipes e povos com outros credos. Mesmo que um ato contratual conduza ao estabelecimento da raya, no fundo há sempre a autoridade arbitral compartilhada que, na condição de instância do direito das gentes, distingue o solo dos príncipes e povos não cristãos e o solo cristão. À época, o papa não repartia a propriedade de terras, mas somente territórios para atividades missionárias. Isso também era a manifestação de uma ordem espacial que distinguia regiões sob o domínio dos príncipes e povos cristãos e regiões de príncipes não cristãos. Na prática, não era possível separar a região missionária e aquela usada na navegação e no comércio. A raya pressupõe, portanto, que os príncipes e povos cristãos tenham o direito de receber do papa um mandato de missão que lhes permitia exercer a atividade missionária em regiões não cristãs, ocupando-as no decurso da missão (SCHMITT, 2014, p. 92, 93).

Ainda que o Tratado de Tordesilhas expresse um novo ordenamento do mundo e autorize aos reinos espanhol e português a tomada de terra a oeste e a leste da 
linha demarcatória estabelecida a partir de Cabo Verde, ela não opera nos termos da estatalidade, mas, sim, referenciando-se na espacialidade medieval. O apelo à mediação papal em um assunto adstrito aos interesses de dois soberanos, nega a soberania vatteliana ${ }^{4}$ e reafirma o primado papal na solução de controvérsias temporais entre as casas senhoriais europeias. Além disso, subjaz ao acordo o compromisso de que as terras e povos a descobrir seriam objeto da evangelização católica, entendendo a conquista do Novo Mundo como projeto compartilhado entre as duas espadas, a temporal e a espiritual. Acrescente-se a isso o não reconhecimento do acordo pelas potências marítimas europeias, o que indicava que os soberanos não entendiam mais o pontífice romano com jurisdição sobre os assuntos de Estado, negando-lhe, dessa forma, autoridade sobre questões que consideravam atinentes à sua esfera de competência soberana.

Ao equiparar a vida dos selvagens da América à condição de estado de natureza, Hobbes (1983) desloca o entendimento antes lhes atribuído pela Antropologia / Geografia colonial. O problema não mais consistia em considerá-los como humanos e dotados de alma ou não, passíveis de cristianizar ou não, mas uma questão de outra natureza. Os selvagens eram humanos como todos nós, mas o que os diferia dos povos ao norte do equador, não era o fato de serem cristãos ou pagãos, mas não possuírem qualquer espécie de governo. A clivagem entre Norte e Sul não mais diz respeito a fiéis e infiéis, mas se faz entre sociedades contratuais e não contratuais, entre aqueles civilizados e não civilizados. Estamos, pois, diante de uma nova espacialidade capaz de oferecer um novo ordenamento e localização do ponto de vista global. Isso deixa algo em aberto: como, então, devem se comportar os povos do Norte em relação aos povos do Sul?

\footnotetext{
${ }^{4}$ Entendemos a soberania vatteliana nos termos de uma das quatro modalidades preconizadas por Krasner (2001). Segundo Vattel (2004), em que o autor se baseia, "toda Nação que se governa por si mesma, sob qualquer forma que seja, sem dependência de nenhum estrangeiro, é um Estado soberano. Os seus direitos são naturalmente os mesmos dos demais Estados. Tais são as pessoas jurídicas que vivem em conjunto em uma sociedade natural submetida às normas do direito das gentes. Para que uma Nação tenha o direito de participar imediatamente nessa grande sociedade, é suficiente que ela seja verdadeiramente soberana e independente, ou seja, que se governe por si mesma, pela sua própria autoridade e por suas leis" (p. 102).
} 
Locke (1983) ao demonstrar a importância da propriedade e do comércio para o bem-estar humano afirma que onde não houver nada durável e raro os homens não seriam motivados a aumentar suas posses, ainda que tivessem terras disponíveis e liberdade para ocupá-las.

Eu pergunto quem atribuiria um valor a dez mil ou a cem mil acres de uma terra excelente, fácil de cultivar e, além disso, bem provida de gado, mas situada no coração da América, se lá não existe nenhuma possibilidade de comerciar com outras partes do mundo e extrair dinheiro da venda dos produtos? [...] assim, no início, toda a terra era uma América, e mais ainda que hoje, pois em parte alguma se conhecia o dinheiro (LOCKE, 1983, p. 53).

Comercializar produtos e adquirir posses ocupando a terra é, assim, uma condição civilizacional, e na medida em que os povos da América estavam isolados e não mantinham intercâmbio com outras partes do mundo, sua condição equiparavase àquela do estado de natureza, ou seja, àquela situação em que todos os povos se encontravam antes de estabelecerem o pacto social. Posteriormente, discorrendo sobre a sociedade política e civil Locke (1983) faz uma série de considerações acerca de diferentes tipos de governos. Ao referir-se às relações entre senhor e servo afirma o seguinte.

[...] há uma outra categoria de servidores, a que damos o nome particular de escravos, que, sendo cativos aprisionados em uma guerra justa, estão pelo direito de natureza sujeitos à dominação absoluta e ao poder absoluto de seus senhores. Como eu disse, estes homens tiveram suas vidas capturadas, e com elas suas liberdades, perderam seus bens $-e$ estão, no estado de escravidão, privados de qualquer propriedade - e não podem nesse estado não poder ser considerados parte da sociedade civil, cujo principal fim é a preservação da propriedade (p. 66).

Na perspectiva lockeana, existem dois tipos de servidores: aqueles que vendem um tempo de serviço em troca de salário; aqueles que são escravos. Os primeiros não são propriedade do seu senhor, já que estão sob seu domínio temporário. Já os segundos, sua condição derivam do fato de terem sido vencidos em uma guerra justa. Nessa situação, eles foram privados de qualquer direito de propriedade, portanto excluídos da sociedade civil, logo privados de seus direitos e por implicação sob o 
poder absoluto de seus senhores. Nesse sentido, não possuem vida civilizada, o que significa, também, exclusão da vida política. Desse raciocínio decorrem duas consequências: a primeira delas relacionada à ideia de guerra justa e a segunda à perda do direito de propriedade.

$\mathrm{Na}$ medida em que a soberania vatteliana se consolida nos termos do direito público europeu ela desloca a discussão da justiça da guerra para a sua legitimidade.

[...] pode acontecer que os contendores estejam de boa fé e, num caso duvidoso, é ainda incerto de qual lado está o direito. Desde que, pois, as Nações são iguais e independentes [...] e não podem erigir-se juízes umas das outras, segue-se que em todos os casos susceptíveis de dúvida, as armas das duas partes beligerantes devem ser consideradas como igualmente legítimas, pelo menos quanto aos efeitos exteriores, e até que a causa seja decidida. Isto não impede que outras Nações julguem a questão por si mesmas com o intuito de decidir qual atitude a tomar e de assistir aquela que lhes parece estar com a razão. Esta conseqüência da independência das Nações não impede que o autor de uma guerra injusta seja efetivamente culpado. Mas se ele agiu em conseqüência de ignorância ou de equívoco incontornável, a injustiça de suas armas não pode ser-lhe imputada (VATTEL, 2004, p. 428).

A igualdade e a independência mutuamente reconhecidas pelos Estados os autorizam a fazer a guerra independentemente de suas causas estarem ou não em acordo com o direito. Ainda que outras unidades políticas possam questionar o ato de guerra, elas não julgam o ato em si, mas apenas no intuito de se posicionar em relação a uma das partes. Pode-se até atribuir a culpa a uns dos envolvidos no caso de guerras tidas como injustas, mas se esse agiu por ignorância ou por equívoco não se pode considerar sua ação como injusta.

A guerra seria justa se fosse a sanção de um ato ilícito; se visasse a uma satisfação ou reparação; se constituísse defesa contra agressão. Contudo, justa ou não, seria legal para todos os beligerantes, porque entre Estados soberanos não há tribunal que determine o direito, nem força irresistível que o imponha (ARON, 2002, p. 865, ênfase no original).

Em outras palavras, não se trata mais da justiça ou da injustiça de uma guerra, assim como entendiam os teólogos medievais, mas de sua legalidade nos termos de 
seu reconhecimento como prerrogativa exclusiva pelos Estados. Unidades políticas soberanas que controlam um determinado território e exercem domínio sobre uma dada coletividade, são iguais e independentes, portanto, somente elas julgam os atos por elas praticados, ainda que esses atos contrariem o direito, o que implica no não reconhecimento de qualquer outra instância superior à vontade do Estado. Para o direito das gentes interestatal europeu, "[...] é justa qualquer guerra interestatal, feita em solo europeu, segundo as regras do direito europeu da guerra, por exércitos organizados dos Estados reconhecidos pelo direito das gentes europeu" (SCHMITT, 2014, p. 153). Fora do âmbito europeu, como no caso do Novo Mundo, por exemplo, pirataria, roubo, escravidão, submissão pela força e morticínio eram permitidos e aceitos pelos Estados territoriais, o que significa que aquilo que se entende como gênese do sistema ou da sociedade internacional moderno foi pensado em função dos interesses europeus, e não dos povos dele excluídos.

\section{Estado de natureza, anarquia e a construção de uma nova espacialidade}

No caso do Tratado de Tordesilhas, a conquista do Novo Mundo é uma atividade missionária concedida pelo papa aos príncipes no intuito de propagar a fé cristã. Logo, "[...] os espanhóis conduzem uma guerra justa e, portanto, podem anexar as terras dos índios se eles se opuserem ao livre comércio (que não é apenas comércio) e à livre missão dos cristãos" (SCHMITT, 2014, p. 93). No âmbito da soberania vatteliana, a guerra, independentemente de ser conduzida nos termos do direito, o que se deve levar em consideração é a sua legitimidade ou ilegitimidade, ou seja, que se desenrole de acordo com aquilo que os próprios Estados reconhecem como correto proceder. Um dos aspectos desse reconhecimento é justamente a sua não criminalização, o entendimento de que a morte ou dano causado pela guerra é tido como legítimo pelos Estados que a levam a cabo, já que assentada nas prerrogativas exclusivas do poder soberano regulado pelo direito público europeu (SCHMITT, 2014). Assim, se já existe entre os próprios Estados europeus a compreensão da legitimidade da guerra como atributo do poder soberano, quaisquer 
guerras por eles travadas são, por definição, justas. Isso significa que o ato de conquista dos selvagens abaixo do Equador, são, por definição, guerras justas.

Em termos hobbesianos, os selvagens vivem em estado de natureza porque não possuem governo e, na acepção lockeana, aqueles vencidos em uma guerra justa se tornam objetos absolutos de seus senhores, podendo, inclusive, ser escravizados. Isso significa que nas duas situações o ordenamento social possível é aquele produto da força. Na medida em que os povos ao sul do equador foram conquistados pelos europeus as regras do contrato a eles não se aplicam ficando, dessa maneira, sujeitos ao arbítrio de seus vencedores. Estamos, portanto, diante das duas situações em que a tomada de terra, no entendimento de Schmitt (2014), gera um novo nomos da terra. Por um lado, temos as sociedades contratuais europeias regulando a tomada de terra em dois planos: do ponto de vista doméstico, a propriedade da terra legalmente garantida pelo contrato; do ponto de vista externo, a prerrogativa de apropriação de novas terras reconhecida pelos poderes soberanos por meio do direito público europeu. Por outro, temos os povos em estado de natureza ao sul do equador que, desprovidos de governo e/ou vencidos em guerra justa, se tornam objeto do arbítrio de seus conquistadores, que sobre eles podem exercer a força indiscriminada - o oposto do que poderiam, em princípio, fazer no âmbito europeu sujeito ao direito das gentes.

Em 1562, Diego Gutiérrez, cartógrafo espanhol da Casa de la Contratación, publica um mapa intitulado América, ou uma nova quarta parte do mundo com uma exata descrição ${ }^{5}$. Mas, ao contrário do planisfério atribuído a Cantino, agora ele não se encontra partido longitudinalmente como previsto pela mediação pontifícia.

Uma das omissões dignas de nota no mapa da América de Gutiérrez é a ausência da famosa linha de demarcação. Esta linha vertical hipotética no Oceano Atlântico serviu como demarcador da divisão entre possessões espanholas e portuguesas na América. Ao oeste da linha estavam as áreas de influência da Espanha. No mapa de Gutiérrez, a linha mais proeminente de demarcação não é uma linha vertical, mas,

\footnotetext{
${ }^{5}$ Medindo 93 x 86 centímetros, o mapa registra a costa leste da América do Norte, a totalidade da América Central e a do Sul, e partes costeiras da Europa e da África. Nele, também, estão representados a Baixa Califórnia, o Rio Amazonas e outros rios da América do Sul, bem como o Lago Titicaca, a Cidade do México etc.
} 
sim, uma linha paralela ou horizontal, representando o Trópico de Câncer a $23^{\circ} 30^{\prime} \mathrm{N}$. Seria de se esperar o paralelo do Cabo Bojador a $26^{\circ} \mathrm{N}$, que passa ao sul das Canárias, e foi usado pelo Papa Martinho V no século $\mathrm{XV}$ para conceder privilégios exclusivos para os portugueses ao sul da costa africana, e pelo papa Nicolau V em Romanus Pontifex (1455) e em todas as bulas subsequentes relacionadas às esferas de influência. Mas a linha de latitude mencionada no Tratado de Cateau Cambrésis, de 1559, e destacada no mapa de Gutiérrez, era a do Trópico de Câncer (HÉBERT, s.d., p. 6,

$7)^{6}$.

A Paz de Cateau-Cambrésis colocou fim a cerca de trinta anos de conflitos territoriais na Europa e compreende, de fato, dois tratados: o primeiro deles, assinado em 2 de abril de 1559, pôs fim ao conflito pelo controle de Calais, tomada aos franceses pelos ingleses em 1558, devolvida ao domínio dos primeiros após a indenização de 500.000 escudos pagos aos segundos; o segundo, assinado em 3 de abril de 1559, pôs fim às chamadas Guerra de Itália envolvendo, por um lado, a França e, por outro, a Espanha e o Sacro Império. O segundo tratado, além de implicar na renúncia da França sobre a Itália, assinala uma nova divisão territorial entre as partes que, ao contrário do ocorrido na disputa entre Portugal e Espanha pelo Novo Mundo, não exigiu a mediação do papado. E mais, aparentemente, acertos verbais entre os negociadores franceses e espanhóis em Cateau Cambrésis

“[...]concluíram que os parâmetros geográficos do tratado não se estenderiam a áreas não europeias, por exemplo, na América, onde os franceses reivindicavam o direito ao comércio, o que a Espanha lhes negava" (HÉBERT, s.d., p. 6) ${ }^{7}$. E essa delimitação aliava interesses estatais a razões de natureza prática.

\footnotetext{
${ }^{6}$ Original: "One of the noteworthy omissions in the Gutiérrez map of America is the absence of the famous line of demarcation. This hypothetical vertical line in the Atlantic Ocean served as the division between Spanish and Portuguese possessions in America. West of the line were Spain's areas of influence. In the Gutiérrez map the most prominent line of demarcation is not a vertical line but rather a parallel or horizontal line, representing the Tropic of Cancer at $23^{\circ} 30^{\prime} \mathrm{N}$. One would have expected instead the parallel of Cape Bojador at $26^{\circ} \mathrm{N}$, which passes south of the Canaries, and was used by Pope Martin $\mathrm{V}$ in the fifteenth century to grant exclusive privileges to the Portuguese southwards down the African coast, and by Pope Nicholas V in Romanus Pontifex (1455) and in all subsequent bulls on the subject of spheres of influence. But the latitudinal line mentioned in the 1559 Treaty of Cateau Cambrésis and prominently shown on the Gutiérrez map was that of the Tropic of Cancer".

${ }^{7}$ Original: "[...] concluded that the geographical parameters of the treaty were not to extend to nonEuropean areas, for example, in America, where the French claimed the right to trade, which Spain denied." 8
} 
Desde o início da história diplomática das Américas, diplomatas, bem como juristas e teólogos espanhóis distintos, concluíram que o papa em Roma não tinha o direito de conceder o que não lhe pertencia. A única reivindicação válida que a Espanha poderia fazer para qualquer parte da América era para as áreas que efetivamente ocupava. Em suas relações com a Espanha no século XVI e no século XVII, outras potências europeias, com exceção de Portugal, reconheciam apenas uma linha, e essa era o Trópico de Câncer. E a Espanha escolheu usar essa linha sem levar em conta as doações papais, por razões práticas. Navegadores poderiam facilmente determinar a localização do Trópico de Câncer. O que o tornou particularmente útil foi o fato de sua linha atravessar o Estreito da Flórida com um canal mais seguro em seu lado cubano ou ao sul. Assim, nenhum navio poderia entrar nas águas das Índias Ocidentais ou do Caribe, nem mesmo no Golfo do México, sem atravessar o Trópico de Câncer. A Espanha estava vitalmente interessada em preservar o monopólio de seu comércio americano e a segurança de suas frotas de prata e ouro. Até 1559, a única ameaça séria ao seu monopólio era a França, e tão logo os invasores e corsários franceses começaram a ser uma ameaça às suas pretensões, tomaramse medidas para persegui-los e eliminá-los em qualquer lugar abaixo do Trópico de Câncer (HÉBERT, s.d., p. 7, 8) ${ }^{8}$.

Assim, a demarcação latitudinal do mapa de Gutiérrez transforma uma antiga paralela, o Trópico de Câncer (latitude $23,4372^{\circ}$ Norte), em um sistema de localização político-espacial. Ela expressa, agora, um acordo diplomático firmado entre poderes soberanos que assinala não espaços de conquista missionária entre dois reinos, mas uma nova ordenação secular da superfície terrestre, as amity lines (linhas de amizade). Ao Norte do Trópico de Câncer os príncipes obedeceriam às regras de convivência mútua do direito público europeu reconhecidas por todos eles; ao Sul do

\footnotetext{
Original: "From the outset of the diplomatic history of the Americas, it was concluded by diplomats, as well as distinguished Spanish jurists and theologians, that the Pope in Rome had no right to give away what did not belong to him, and that the only valid claim that Spain could assert to any part of America was to those areas it effectively occupied. In their sixteenth- and seventeenth-century relations with Spain, other European powers, with the exception of Portugal, recognized only one line, and that was the Tropic of Cancer. And Spain had chosen to use that line without regard for papal donations, for practical reasons. Navigators could easily ascertain the location of the Tropic of Cancer. What made it particularly useful was that Cancer ran through the Straits of Florida with the safest channel well on its Cuban, or southern, side. So no ship could enter West Indian or Caribbean waters, not even the Gulf of Mexico, without crossing the Tropic of Cancer. Spain was vitally interested in preserving the monopoly of its American trade and the safety of its silver and gold fleets. Until 1559 the only serious threat to its monopoly was France, and no sooner did French interlopers and corsairs begin to be a nuisance than measures began to be taken to pursue and eliminate them anywhere below the Tropic of Cancer."
} 
Trópico de Câncer os acordos aceitos no âmbito europeu não teriam validade em suas disputas por conquista e tomada de terra.

Nessa linha terminava a Europa e começava o Novo Mundo. Nela terminava o direito europeu, pelo menos o "direito público europeu". Em consequência, também terminava a circunscrição da guerra efetivada pelo direito das gentes, e a luta pela tomada de terra tornava-se desenfreada. Do outro lado da linha começa uma zona ultramarina na qual, na ausência de um limite jurídico para a guerra, só vale o direito dos mais fortes. A peculiaridade dessas "linhas de amizade" reside no fato de que, ao contrário da raya, elas demarcam um espaço de luta entre as partes de um tratado que aspiram à tomada de terra, mas carecem de pressupostos compartilhados e de uma autoridade comum, embora ainda vivam da recordação da unidade cristã da Europa. As partes dessa relação só concordam no que diz respeito à liberdade nos novos espaços que começam do outro lado da linha. A liberdade consiste no fato de que a linha demarca uma área para o uso livre e irrefreável da violência. Admite-se como natural a presunção de que somente os príncipes europeus cristãos podem participar da tomada de terra e ser admitidos como partes nesses tratados. Mas o ponto de convergência entre príncipes e nações cristãs não contém uma instância arbitral comum, legitimante em termos concretos, tampouco outro princípio de repartição que não seja o direito do mais forte e, finalmente, a ocupação efetiva. Daí tinha de surgir a noção geral, segundo a qual tudo o que ocorre "além da linha" permanece completamente fora das apreciações jurídicas, morais e políticas que eram aceitas aquém da linha. Isso significa que um imenso desafogo da problemática intraeuropeia, e nele reside o sentido famoso e famigerado de beyond the line [além da linha] (SCHMITT, 2014, p. 95, 96).

O que a perspectiva contratualista faz mais tarde é oferecer um novo sentido para as linhas de amizade racionalizando-as a partir do estado de natureza. Aquilo que começa como um arranjo diplomático-estratégico de atores soberanos para a tomada de terra pela força no Novo Mundo adquire um novo significado como sociedades regidas e não regidas pelo contrato social.

É evidente que Hobbes não estava impressionado somente pelas guerras civis religiosas na Europa, mas também pelo impacto de um novo mundo. Ele se refere ao "estado de natureza", mas não o faz no sentido de uma utopia destituída de espaço. O estado de natureza de Hobbes é uma terra de ninguém, mas não é, nem de longe, um lugar nenhum. É localizável, e Hobbes o localiza, entre outros lugares, no Novo Mundo. No Leviatã, os "americanos" são expressamente 
mencionados como exemplo do caráter de lobo dos homens em estado de natureza, e em Behemoth ele se refere às atrocidades cometidas pelos católicos espanhóis no Império Inca. Em outras passagens, entretanto, sobretudo no estágio posterior de seu pensamento, a elaboração conceitual abandona a experiência concreta de tempo e espaço. O estado de natureza passa a ser tratado menos como fato histórico concreto do que como construção concebida de um ponto de vista hipotético, mas isso não anula a conexão histórica, importante para nós, com a existência das linhas de amizade (SCHMITT, 2014, p. 98, ênfase no original).

Assim, as linhas de amizade transformam a terra incógnita ptolomaica em espaço livre para o exercício da força e da violência e os contratualistas transformam as linhas de amizade em margens de duas espacialidades distintas: uma situada ao norte do Trópico de Câncer civilizada e regida pelo contrato, outra ao sul do Trópico de Câncer selvagem e sem lei, porque sem contrato, portanto sujeita a um ordenamento a ser imposto pela força. O Trópico de Câncer, dessa maneira, é mais do que uma simples paralela traçada em um espaço isotrópico, mas expressa uma estruturação simbólica do mundo que tem na Europa o seu centro civilizado separando-a do outro selvagem relegado ao estado de natureza. Combinadas, as linhas de amizade $\mathrm{e}$ as teses contratualistas constituem um novo nomos de ordenamento do espaço global e de localização dos habitantes da ecúmena, ao mesmo tempo em que permite a consolidação dos Estados territoriais europeus.

Na perspectiva do direito das gentes, o sentido das linhas de amizade dos séculos XVI e XVII residia no fato de que grandes espaços de liberdade haviam sido delimitados como zonas de combate para a luta pela repartição do Novo Mundo. Como justificativa prática, pôde-se alegar que a delimitação de uma livre zona de combate representou um desafogo deste lado da linha, o do âmbito do direito público europeu um espaço de paz e de ordem -, o qual não foi tão diretamente ameaçado pelos acontecimentos do outro lado da linha, como seria se tal delimitação não houvesse existido. A delimitação de uma zona de combate fora da Europa servia à circunscrição da guerra europeia - eis o seu sentido e a sua justificativa nos termos do direito das gentes europeu (SCHMITT, 2014, p. 99, 100).

As linhas de amizade permitem que os conflitos territoriais na Europa arrefeçam, pois deslocam a tomada de terra para o teatro do Novo Mundo. Isso 
significa, por um lado, os Estados europeus criarem instrumentos que regulamentam o uso da força e a realização da guerra. Na medida em que a guerra, ao contrário das faidas medievais (guerras privadas travadas entre os senhores feudais), se torna, cada vez mais, prerrogativa de governantes investidos de prerrogativas soberanas, o recurso à força e à violência é cada vez mais privativo do soberano na solução de controvérsias com outros soberanos. Nessa perspectiva, a guerra ainda é continuação da política por outros meios, mas apenas no âmbito dos Estados territoriais europeus que se reconhecem como iguais. Onde não existem mais iguais, como no caso da região ao sul do Trópico de Câncer, não existem mais regras a serem respeitadas para o uso da força e a guerra é simplesmente o exercício da violência entre os príncipes europeus e/ou contra selvagens no processo de tomada de terra, portanto de conquista de territórios.

A última tomada de terra europeia ocorreu na Conferência de Berlim (novembro de 1884 a fevereiro de 1885) quando 14 potências europeias acordaram a ocupação colonial da África. A partir de então não havia mais terras livres a serem tomadas. No século $\mathrm{XX}$, o processo de descolonização estendeu a estatalidade para além do mundo europeu, o que alterou drasticamente a espacialidade pensada como sociedades contratuais ao norte do Trópico de Câncer e não contratuais ao sul do Trópico de Câncer. E mais, as justificativas para tomada de terra perdiam sentido e com ela a ideia de que o recurso à força se justificativa nos termos da soberania vatteliana e das pretensões territoriais dos Estados europeus. O resultado foi a constituição de um sistema de estados em que todos eles são tidos como juridicamente soberanos, portanto, iguais, mas dependentes de seus recursos de força para fazerem valer suas prerrogativas de soberania. Instaura-se, assim, uma competição pelos recursos de força em nível sistêmico, estendendo a espacialidade da anarquia do estado de natureza a toda ambiência internacional.

\section{O campo de forças e a obliteração da política}


A constituição das Relações Internacionais como um campo de conhecimento acadêmico, após a Primeira Grande Guerra, consolidou a noção do internacional como similar ao estado de natureza em que predomina a anarquia. Desde então, na maioria das interpretações, ele é pensado como um campo de forças a partir do qual os Estados estruturam suas interações tanto de natureza conflitiva como cooperativa. Anarquia e estado de natureza transformam-se então em pressupostos analíticos por meio dos quais a ideia de campo de forças (DURAND, LÉVY e RETAILLÉ, 1993) emerge em diferentes conotações explicativas dos fenômenos internacionais.

Para as Ciências Físicas um campo é "uma região que rodeia um corpo carregado eletricamente, um corpo magnetizado ou uma massa suscetível a um efeito qualquer" (HARTMANN-PETERSEN e PIGFORD, 1991, p. 52). Assim, a região vizinha a um objeto carregado eletricamente constitui um campo elétrico ou uma região em torno de um corpo em que outro corpo é atraído como consequência de suas respectivas massas constitui um campo gravitacional, por exemplo. O raciocínio básico é o de que um campo se constitui sempre quando uma força - seja a eletricidade, o magnetismo ou a gravidade - age sobre sua vizinhança, atraindo-a para a sua zona de influência. A força gravitacional do sol, por exemplo, mantém os planetas em órbita elíptica ao seu redor, ao mesmo tempo em que é contrabalançada pelas forças gravitacionais advindas das respectivas massas dos planetas. Isso pressupõe que qualquer mudança na força gravitacional de um ou mais desses corpos celestes pode alterar todo sistema solar colocando em risco, inclusive, sua própria existência.

Por analogia, e não por equivalência, do ponto de vista dos fenômenos internacionais podemos considerar como um campo aquela região do espaço terrestre suscetível de sofrer influência de uma determinada força. Mas, contrariamente às Ciências Físicas, o significado de forças adquire denotação totalmente distinta. Aqui, a força compreende a capacidade de um determinado agente em resistir ao outro e conseguir empregá-la de forma capaz de vencer a resistência daquele que se the opõe. 
Podemos chamar de força potencial o conjunto dos recursos materiais, humanos e morais de que cada unidade dispõe teoricamente; e de força real a parte desses recursos efetivamente utilizada para a condução da política externa, durante a guerra ou em tempos de paz. Na guerra, a força real se aproxima da força militar (sem que os dois conceitos possam ser confundidos inteiramente, porque o curso das operações é determinado em parte por modalidades não-militares de luta). Em tempos de paz, a força real distingue-se da força militar, porque as divisões do exército, as frotas navais e os esquadrões aéreos em existência, mas que por qualquer motivo não são empregados, constituem um dos instrumentos a serviço da política externa (ARON, 2002, p. 101, ênfase no original).

Forças, então, constituem o conjunto de meios potenciais e efetivos que os Estados podem mobilizar para resistir a outros agentes similares em tempos de guerra e de paz. Nesse sentido, ela difere da ideia de poder que é a capacidade que o agente possui de aplicar os meios de força em uma situação de beligerância ou de oposição aos seus interesses e objetivos. Conceber a espacialidade territorial dos Estados como um campo de forças significa, então, que cada um deles a partir de um determinado ponto no espaço, controla os recursos humanos e materiais disponíveis em uma determinada configuração espacial, ao mesmo tempo em que se contrapõe a outras configurações espaciais controladas por agentes políticos com objetivos e pretensões similares aos seus.

[No mundo como campo de forças] a tendência para aumentar o número de grupos humanos foi reforçada, mas também bloqueada pela formação de Estados, que conseguiram, sob várias condições, capturar uma grande parte dos recursos da sociedade. O Estado aparece então como uma estrutura territorialmente rígida que incorpora agenciamentos não estatais ou se ajusta "em força" aos outros Estados [...] Essa lógica engendra configurações que estruturalmente produzem violência porque cada Estado, real ou virtual, tende a aumentar seu poder conservando ou aumentando seu território, um reservatório de recursos, pessoas e riqueza potencial, o que implica opor-se a seus vizinhos e neutralizar qualquer tentativa de uma nova demarcação que possa levar à amputação territorial (DURAND, LÉVY e RETAILLÉ, 1993, p. 23, 24) ${ }^{8}$.

\footnotetext{
${ }^{8}$ Original : "La tendance à la coalescence de groupes humains de plus en plus vastes a été confortée mais aussi bloquée par la formation des Etats, qui ont réussi, dans des conditions diverses, à capter une part très importante des ressources de la société. L'Etat apparait dês lors comme une structure territorialement rigide qui, soit incorpore les ensembles non étatiques, soit s'ajuste " en force» aux autres Etats [...] Cette logique engendre des configurations qui produisent structurellement de la
} 
O campo de forças assenta-se, então, em um conjunto de processos que têm na existência e na integridade territorial dos Estados o seu fundamento. Ele emerge do longo processo que pôs fim ao ordenamento medieval e tem nos acordos de Vestefália seu marco simbólico. O princípio cujus regio, ejus religio abriu um campo de possibilidades para uma nova espacialidade orientada pela intencionalidade do senhor da terra que, cada vez mais, estendeu o seu domínio político sobre o conjunto de mundos feudal. O resultado foi uma nova configuração espacial, em que agentes soberanos organizados em unidades político-administrativa-territoriais de uma população empreenderam um amplo conflito pelo domínio crescente de territórios e a fixação de seus limites físicos. Assimiladas, essas ideias irão constituir uma matriz interpretativa para as relações internacionais orientadas por três pressupostos.

O primeiro pressuposto, e o mais profundamente arraigado, é que a soberania do Estado moderno requer espaços claramente delimitados territorialmente. O estado moderno difere de todos os outros tipos de organização porque afirma a soberania absoluta de seu território. A defesa da segurança em seu domínio espacial particular e a atividade política que ela traz é o objetivo principal do Estado territorial. Personificado por um tempo na pessoa do monarca - ou outro líder dentro da hierarquia de "categorias" que vão desde o mais humilde camponês até os guerreiros, padres e nobres - a soberania é atualmente atribuída ao território (AGNEW, 1998, p. 85) . $^{9}$

Dessa perspectiva emerge a visão que tradicionalmente se expressa nos mapas políticos. Trata-se de um mundo em que poderes soberanos dominam blocos de espaço e disputam entre si o controle e a posse de regiões da terra. É a visão

violence car chaque Etat, réel ou virtuel, tend à accroítre sa puissance en conservant ou em augmentant son territoire, réservoir de ressources, d'hommes et de richesses potentielles, ce qui implique de s'opposer à ses voisins et de neutraliser toute velléité de redécoupage pouvant aboutir à une amputation."

${ }^{9}$ Original: "El primer supuesto, y el más arraigado, es que la soberania del Estado moderno requiere espacios claramente delimitados territorialmente. El Estado moderno difiere de todos los demás tipos de organización porque afirma la soberanía absoluta de su territorio. Defender la seguridad en su dominio espacial particular y la actividad política que lleva aparejada es el principal objetivo del Estado territorial. Personificada durante un tiempo en la persona del monarca - u otro líder dentro de la jerarquía de "categorías» que van desde el campesino más humilde a los guerreros, sacerdotes y nobles- la soberanía actualmente se atribuye al territorio." 
clássica do campo de forças em que, para garantir a segurança do território, as unidades políticas soberanas devem acumular meios de força, atividade política estatal por excelência. Na linha de argumentação derivada de Hobbes (1983) a política interestatal é sempre uma luta de todos contra todos e aquele que dispuser dos melhores meios de força domina maiores blocos de espaço e, com isso, se impõe sobre os demais.

$\mathrm{Na}$ verdade, trata-se da extensão à superfície terrestre do que ocorrera no espaço particular europeu durante a constituição da estatalidade moderna, em que os príncipes disputavam território para controlar cada vez mais o conjunto de mundos, o que os colocava em conflito com outras casas senhoriais com pretensões similares. Ainda que as linhas de amizade tenham arrefecido a luta territorial no âmbito europeu e declinado na Primeira Grande Guerra, esse modelo tornou-se a base do entendimento das relações interestatais orientando, até a atualidade, grande parte das análises geopolíticas e de relações internacionais.

Para os analistas geopolíticos, o sistema internacional é o grande elemento formador do estado em seu próprio território. Os argumentos geopolíticos afirmam comumente que as relações entre estados têm uma lógica e influência próprias e que, por conseguinte, a formação do estado segue rigorosamente o sistema de relações vigente entre eles. Num esforço característico, James Rosenau distingue quatro "padrões de adaptação nacional" à política internacional: aquiescente, intransigente, fomentador e preservador. $O$ estado intransigente, por exemplo, "pode tentar fazer com que o seu ambiente se coadune às suas estruturas vigentes", enquanto o estado fomentador "pode procurar moldar as exigências de suas estruturas vigentes ao seu ambiente atual" (Rosenau 1970: 4). Cada um desses padrões, no entender de Rosenau, têm consequências distintas para o caráter do executivo, para a natureza do sistema partidário, para o papel do legislativo, do militar e outras coisas mais (Rosenau 1970: 6-8). Do mesmo modo, aquilo que William Thompson denomina perspectiva da "sociedade global" com relação à guerra e às relações internacionais atribui uma autonomia expressiva à política e considera que os estados individuais reagem fortemente à estrutura das relações entre todos os estados; portanto, enquadra-se claramente no quadrante geopolítico. Não surpreende, pois, que para nós os modelos geopolíticos de formação do estado, da guerra e das relações internacionais se articulem estreitamente entre si [...] (TILLY, 1996, p. 55). 
Constitui-se, dessa maneira, um padrão de entendimento, tanto no que respeita a Geopolítica quanto as Relações Internacionais, em que a ideia de estatalidade enfatiza a autonomia do Estado e a configuração que assumiu na Modernidade como produto das interações independentes entre unidades políticas soberanas. Desprezase, assim, uma série de elementos, principalmente o papel da ordem capitalista que também emergiu no mesmo período, não se combinasse aos interesses de concentração e acumulação de poder por parte das casas senhoriais europeias contribuindo, desta maneira, para que o Estado assumisse sua forma contemporânea. Para que essa ideia se consolidasse foi preciso supor, também, a separação entre política doméstica e política internacional.

O segundo pressuposto chave é que existe uma divisão fundamental entre questões "interiores" e "exteriores" no mundo moderno. Isto é apoiado pela concepção compartilhada pela teoria política ocidental de que os estados são semelhantes às pessoas que lutam para ganhar poder e fortuna em um mundo hostil. As realizações econômicas e políticas de um Estado são sempre alcançadas em detrimento de outros, e é por isso que a cultura cívica e o debate político só são possíveis dentro dos limites do Estado. No exterior, a razão de Estado (a busca pelos interesses de um Estado) constitui a regra suprema. Essa concepção determina os processos de competição política e econômica no nível do sistema estatal (AGNEW, 1998, p. 85, 86) ${ }^{10}$.

O pressuposto do contrato no nível doméstico e o do estado de natureza no nível externo conduzem à concepção da política internacional contraposta à política interna. Enquanto no primeiro, a partir do contrato entre cidadãos livres ou entre súditos e governantes, a política se expressa em um plano regulado por normas legitimamente reconhecidas pela população sujeita ao domínio estatal, e garantido pelo monopólio do uso da força, no segundo essa operaria em bases totalmente diferentes. A política internacional seria objeto de Estados soberanos que não

\footnotetext{
10 Original: "El segundo supuesto clave es que existe una división fundamental entre asuntos «interiores» y «exteriores» en el mundo moderno. Esto se apoya en la concepción que comparte la teoría política occidental de que los Estados son similares a personas que se enfrentan para lograr poder y fortuna en un mundo hostil. Los logros económicos y políticos de un Estado siempre se consiguen a expensas de otros, motivo por el que la cultura cívica y el debate político sólo son posibles dentro de los límites del Estado. En el exterior, la razón de Estado (la búsqueda de los intereses de un Estado) constituye la regla suprema. Esta concepción determina los procesos de competencia política y económica a nivel del sistema de Estados."
} 
reconhecem nenhuma autoridade superior e, portanto, encontra-se sujeita aos interesses e objetivos estatais e a estabilidade sistêmica é produto da força daqueles mais poderosos ou resultado da aquiescência das demais unidades políticas. Ainda que se reconheça um corpo de normas aplicáveis a todos eles, não existe, como no caso da esfera doméstica, nenhum poder político maior capaz de impô-las, o que leva os Estados a somente contarem consigo mesmos para realizarem seus objetivos, 0 que gera desconfiança recíproca entre eles

(MORGENTHAU, 2003; WALTZ; 2002). Subjacente a esta concepção de política internacional está o pressuposto de que contrariamente ao que ocorre no contexto interno, o ambiente internacional é anárquico e, portanto, as ações dos Estados dependem mais da correlação de forças entre eles, da quantidade dos meios de força que conseguem acumular, e não de normas a serem seguidas como ocorre no plano doméstico.

Terceiro, e por último, o Estado territorial serve como o "contentor" geográfico da sociedade moderna. A organização política e social é definida do ponto de vista deste ou daquele Estado. Portanto, escrevemos e falamos desembaraçadamente da sociedade

"americana" ou "italiana", como se os limites do Estado fossem também os limites dos processos sociais ou políticos que nos interessavam, excluindo, assim, outras escalas de pensamento ou análise geográfica. Isso ocorre porque o estado é geralmente considerado o garantidor da ordem social nas sociedades modernas. O Estado substitui a ordem cultural autoperpetuada antes encontrada nas chamadas sociedades tradicionais [...] (AGNEW, 1998, p. 86) ${ }^{11}$.

Esse terceiro pressuposto é como um corolário dos outros dois. Na medida em que o Estado se impõe territorialmente sobre blocos do espaço e a ideia de contrato social conduz ao seu reconhecimento como instituição política suprema no âmbito doméstico, a consequência imediata é pensar sua projeção externa como

\footnotetext{
11 Original: "Tercero, y último, el Estado territorial sirve de «contenedor» geográfico de la sociedad moderna. La organización política y social está definida desde el punto de vista de tal o cual Estado. Por ello, escribimos y hablamos desinhibidamente de sociedad «americana» o «italiana», como si los límites del Estado fueran también los límites de los procesos sociales o políticos que nos interesaran, quedando así excluidas otras escalas de pensamiento o análisis geográfico. Esto se debe a que se suele considerar que el Estado es el garante del orden social en las sociedades modernas. El Estado sustituye al orden cultural auto-perpetuado que podría encontrarse en las sociedades llamadas tradicionales [...]"
} 
expressando a própria sociedade que o institui. A sociedade, assim como acontece em várias abordagens em Relações Internacionais, se subsume no Estado. Ainda que não o faça na mesma acepção organicista postulada por Ratzel (1988), mas da relação entre um ordenamento doméstico em que a violência generalizada é contida pela exclusividade do uso da força por uma autoridade central e um sistema de estados regido pelo poder do mais forte, a subsunção da sociedade pelo Estado anula a primeira diante do segundo. A sociedade é, assim, contida pelas fronteiras territoriais dos Estados e ela, do ponto de vista externo, não é definida em termos de suas características, mas do próprio Estado que afirma representá-la. Isso exclui das ações dos Estados em suas relações com outros Estados, qualquer interferência da ordem doméstica mantendo a exclusividade e a independência de suas decisões reafirmando, dessa forma, as prerrogativas soberanas de declarar, dar continuidade ou suspender um conflito à revelia da vontade da população objeto de seu domínio.

Esses três pressupostos conjuntos são os fundamentos de uma concepção de estado sem horizontes temporais, como se fosse a única fonte de poder no mundo moderno. O primeiro pressuposto data do período da história europeia em que a soberania passou da pessoa do monarca para o Estado e seus cidadãos. Na Europa, esse processo não aconteceu da noite para o dia, mas durou do século XV ao século XIX. $O$ segundo pressuposto data dos últimos cem anos, embora o contraste dos assuntos internos com os assuntos externos tenha suas raízes nas doutrinas do mercantilismo econômico do século XVII. Juntos, eles servem para situar o Estado territorial moderno à margem da história em geral e da história de Estados específicos, em particular. Eles definem um mundo formado exclusivamente por atores territoriais similares que atingem seus objetivos controlando blocos de espaço (AGNEW, 1998, p. $86)^{12}$.

\footnotetext{
12 Original: "Estos tres supuestos unidos son los cimientos de una concepción de estatalidad sin horizontes temporales, como si fuera la única fuente de poder en el mundo moderno. El primero data del período de la historia europea en el que la soberanía pasó de la persona del monarca al Estado y sus ciudadanos. En Europa, este proceso no ocurrió de la noche a la mañana, sino que se prolongó desde el siglo XV hasta el XIX. El segundo data de los últimos cien años, aunque la contraposición de los asuntos interiores a los exteriores tiene sus raíces en las doctrinas del mercantilismo económico del siglo XVII. Juntos sirven para situar al Estado territorial moderno al margen de la historia en general y de la historia de Estados concretos, en particular. Definen un mundo formado exclusivamente por actores territoriales similares que logran sus fines mediante el control de bloques de espacio."
} 
O que o entendimento das interações internacionais como um campo de forças que emana da anarquia e do estado de natureza provoca é a obliteração das relações desiguais a partir das quais o sistema ou a sociedade internacional se constituiu. Buscar um padrão permanente para as relações internacionais que remeta à Tucídides e à Guerra do Peloponeso, como fazem algumas leituras convencionais realistas, é ignorar a sincronia e a diacronia dos fenômenos sociais e humanos, que eles variam histórica e espacialmente. Assim, pensar o Estado moderno e as suas relações é equivalente a pensar as cidades-estados e suas relações há mais de 2000 anos. O Estado, desta maneira, é uma instituição, uma espécie de divindade que existe para além do tempo e do espaço. Reifica-se, dessa maneira, o próprio Estado moderno, umas das várias formas de organização política que floresceram na Europa a partir do século IX (TILLY, 1996), já que esse é apresentado como atemporal, natural e permanente. Reificando-se o Estado na sua forma moderna-ocidental, reifica-se, também, o próprio sistema de estados e o ordenamento desigual a que a sua expansão pela superfície terrestre também deu origem. Em outras palavras, consagrase, do ponto de vista dos povos ao sul do Trópico de Câncer, o mesmo processo que os relegou, desde o início, à condição subordinada no sistema de estados.

\section{Considerações Finais}

O entendimento das relações internacionais como anárquicas constrói uma narrativa alternativa ao processo de construção do moderno sistema de estados. Pensado originalmente como um recurso heurístico para se entender a organização política que emerge com a Modernidade, o estado de natureza acaba se materializando no modo de vida das populações descobertas no chamado Novo Mundo. Termina, assim, por criar uma clivagem, por meio das linhas de amizade, entre duas ordens político-espaciais: aquela situada ao norte do Trópico de Câncer e aquela situada ao sul desse mesmo trópico. Ao Norte, sociedades assentadas hipoteticamente no contrato entre governantes e súditos (HOBBES, 1983) ou livremente entre governados para constituir a sociedade política (LOCKE, 1983); ao 
Sul, sociedades não contratuais vivendo anarquicamente no estado de natureza. Ao Norte, emanando do interior para o exterior relações assentadas no direito público europeu que regulam a guerra entre príncipes soberanos; ao Sul, a luta aberta entre estes príncipes soberanos pelo domínio das terras descobertas e apropriação de seus recursos. Vivendo em estado de natureza as populações do Novo Mundo sujeitas ao império da força e da expropriação pelo Norte.

$\mathrm{Na}$ medida em que a estatalidade se consolidou e se expandiu da Europa Ocidental para o mundo após o processo de descolonização, a percepção do internacional como um campo de forças anárquico e em condição de estado de natureza se estendeu ao conjunto do sistema internacional ou da sociedade internacional. Incorporada por grande parte das abordagens Geopolíticas e de Relações Internacionais, essa ideia se tornou central na consolidação desses dois campos de conhecimento no entendimento do internacional. Contudo, pelo que argumentamos no decorrer deste ensaio, trata-se de uma construção histórica decorrente das interações entre unidades políticas soberanas europeias na tomada de terra do Novo Mundo, processo este que instaurou uma hierarquia políticoespacial entre os povos ao Norte e ao Sul do Trópico de Câncer. A pergunta a se fazer é a seguinte: quais são as implicações da aceitação acrítica da ideia de anarquia e de estado de natureza para o nosso entendimento das relações internacionais - já que somos povos situados ao Sul do Trópico de Câncer. Devemos, simplesmente, descartar essas duas categorias analíticas na interpretação das relações internacionais?

Para responder a essa pergunta temos que pensar primeiramente qual é o lugar a partir do qual podemos pensar nossa condição no mundo e, por implicação, no sistema internacional ou na sociedade internacional. O ponto de partida, para a construção do internacional em sua acepção hodierna, é a ideia de que os chamados descobrimentos das Grandes Navegações descortinaram a superfície da terra e tornaram o mundo mais conectado como nunca havia sido até então. Mas essa é uma narrativa construída a partir da visão europeia do mundo.

A expansão ultramarina dos europeus expressa sua chegada tardia a rotas traçadas anteriormente pelos povos antigos. Rotas como aquelas trilhadas por Vasco 
da Gama e seus sucessores nada mais eram do que variantes das antigas relações entre o Oriente e o Ocidente estabelecidas por antigas civilizações (BOUCHERON, 2015). Visto na perspectiva dos povos descobertos, eram os europeus, sim, que estavam descobrindo um mundo que há muito, em diferentes épocas, já se encontrava descortinado. Em outras palavras, o mundo, ainda que em ritmo totalmente diferente do contemporâneo, já era de certa forma mundializado e interdependente, seja porque as civilizações expandiram-se via conquista e absorveram o conjunto de mundos, seja porque o fluxo migratório e de produtos ao circularem por rotas transcontinentais vinculou pontos dispersos da superfície terrestre.

O nosso desafio consiste, dessa maneira, não olhar o mundo a partir das caravelas espanholas e portuguesas que por aqui aportaram, mas de entendê-lo do ponto de vista daqueles que aqui estavam quando os europeus aqui chegaram. Foram os europeus que diante do desconhecimento que possuíam do mundo o categorizaram e o classificaram de acordo com o lugar que consideravam ocupar em relação aos outros povos. Não que outras civilizações e povos não tivessem, também, feito uma leitura do outro a partir do seu próprio sistema de referência. A diferença reside no fato de que os grandes impérios anteriores demandavam dos povos conquistados tributos e a sua aquiescência ao domínio, enquanto os europeus, ao mesmo tempo em que os submetiam pela força, consideravam-se com a prerrogativa de convertê-los ao seu próprio sistema de referência. Foi assim com o projeto inicial da catequese civilizadora, com a clivagem sociedades contratuais e em estado de natureza, com a ideia de Estados desenvolvidos e subdesenvolvidos ou modernos e não modernos etc. É assim, também, com a ideia de Estados democráticos e não democráticos, de economia de livre-mercado e economias estatizantes e por aí vai. Mas persiste o problema: como pensar um mundo assim ordenado a partir do nosso lugar no mundo? Mas uma vez, os Descobrimentos nos oferecem uma pista.

[...] o espetacular sucesso da colonização espanhola no seio das etnias indígenas foi alterado pelo uso que dela se fazia: mesmo subjugados, ou até consentindo, muitas vezes esses indígenas usavam as leis, as práticas ou as representações que lhes eram impostas pela força ou pela sedução, para outros fins que não os dos conquistadores. Faziam com elas outras coisas: subvertiam-nas a partir de dentro - não rejeitando-as 
ou transformando-as (isto acontecia também), mas por cem maneiras de empregá-las a serviço de regras, costumes ou convicções estranhas à colonização da qual não podiam fugir. Eles metaforizavam a ordem dominante: faziam-na funcionar com outro registro. Permaneciam outros, no interior do sistema que assimilavam e que os assimilava exteriormente. Modificavam-no sem deixá-lo. Procedimentos de consumo conservavam a sua diferença no próprio espaço organizado pelo ocupante (DE CERTAU, 1998, p. 94, 95).

Ainda que esse comportamento possa parecer uma situação limite ou argumentar que ela não impediu o extermínio de grande parte da população pelos descobridores europeus, o relato acima nos proporciona uma alternativa para a nossa indagação. Não se trata de abdicar da utilização de categorias como anarquia e estado de natureza, mas de lê-las a partir de outro registro. Trata-se de entendêlas como uma construção histórica do Norte para engendrar uma ordem políticoespacial que situa os Estados e as sociedades do Sul, por meio qualquer de clivagens, como subordinadas no ordenamento internacional. Ler a anarquia e o estado de natureza sob o prisma das desigualdades estruturais, subverter seu sentido original de atemporalidade e de universalidade como convencionalmente nos é apresentado pelas teorias de relações internacionais produzidas no Norte, especialmente aquelas de matriz angloestadunidense. Isso requer, por um lado, quebrar o princípio do Estado como contendor da sociedade e, por outro, romper a dicotomia ordem doméstica / ordem externa.

A narrativa convencional de construção do internacional a partir da anarquia e do estado de natureza é um relato ocidental de sua própria gênese, isto é, ao mesmo tempo em que descreve o que se encontra além do Trópico de Câncer, demarca um espaço. Isso porque como, argumenta De Certau (1998), a descrição é um ato culturalmente criador e de fixação.

[A descrição] tem até poder distributivo e força performativa (ela realiza o que diz) quando se tem um certo conjunto de circunstâncias. Ela é então fundadora de espaços. Reciprocamente: onde os relatos desaparecem (ou se degradam em objetos museográficos), existe perda de espaço: privado de narrações (como se constata ora na cidade, ora na região rural), o grupo ou indivíduo regride para a experiência, inquietante, fatalista, de uma totalidade informe, indistinta, noturna. 
Considerando o papel do relato na delimitação, pode-se aí reconhecer logo de início a função primeira de autorizar o estabelecimento, o deslocamento e a superação de limites e, por via de consequência, funcionando no campo fechado do discurso, a oposição de dois movimentos que se cruzam (estabelecer e ultrapassar o limite) de maneira que se faça do relato uma espécie de quadrinho de "palavras cruzadas" (um mapeamento dinâmico do espaço) e do qual a fronteira e a ponte parecem as figuras narrativas essenciais (DE CERTAU, 1998, p. 209).

Contudo, ao demarcar o espaço, o relato constitui, também, um domínio ou uma região a partir do qual o outro é percebido e compreendido. Fronteira, "[...] nas línguas espanhola (frontera), francesa (frontière) e inglesa (frontier) derivam do antigo latim fronteria ou frontaria, que indicava a parte do território situado in fronte, ou seja, nas margens" (ZIENTARA, 1989, p. 306, 307). Para os romanos, a fronteria referia-se a uma área determinada em suas margens e não a uma linha divisória entre regiões, como se pensa atualmente. Entender a fronteira nesses termos significa pensá-la como margens de circulação e que permitem o contato entre o nós e o outro, aquele que está em frente, ao invés de isolado por uma linha que separa duas unidades políticas como requer a soberania vatteliana. Para a divisão de regiões, ou seja, confim entre dois campos, os romanos recorriam ao termo limes (limites) - pensado como delimitação de locais estratégicos para a proteção e a defesa militar. Assim, do ponto de vista de seu significado anterior a Modernidade, a fronteira não é uma linha que estabelece um muro entre dois mundos como aparece nos mapas-políticos, mas um ponto de conexão entre limites que demarcam uma região.

Problema teórico e prático da fronteira: a quem pertence a fronteira? $\mathrm{O}$ rio, a parede ou a árvore faz fronteira. Não tem o caráter de não-lugar que o traçado cartográfico supõe no limite. Tem um papel mediador.

Também a narração o faz falar: "Pára!" - diz a floresta de onde sai o lobo. "Stop" - diz o rio mostrando o seu jacaré. Mas este ator, pelo simples fato de ser a palavra do limite, cria a comunicação assim como a separação: e muito mais, só põe uma margem dizendo aquilo que o atravessa, vindo da outra margem. Articula. É também uma passagem. No relato, a fronteira funciona como um terceiro. Ela é um "entre dois" "um espaço entre dois", Zwischenraum", diz um maravilhoso e irônico poema de Morgenstern sobre a "clausura" ou "recinto cercado" (Zaun), 
que rima com "espaço" (Raum) e "ver através de" (hindurchzuschaun) (DE CERTAU, 1998, p. 213, ênfase no original).

A anarquia e o estado de natureza, por um lado, e por outro, o direito público europeu constituem narrativas do internacional que demarcam uma região para a qual as linhas de amizade estabelecem uma fronteira, ou seja, as margens de dois mundos distintos: a Europa e o Novo Mundo. Mas se as linhas de amizade dizem onde termina a Europa - domínio do contrato e do direito das gentes europeu -, elas dizem, também, onde começam os confins da Europa, ou seja, onde cessa esse mesmo direito e esse mesmo contrato. Pelas margens das linhas de amizade estabelece-se, assim, a separação, mas ao mesmo tempo em que dizem quem a atravessa e quem está no seu oposto, elas permitem que de ambas as margens dois mundos distintos se vejam e se interpretem. E é sob o signo deste olhar que é construída a leitura político-espacial do mundo e, por implicação, do internacional.

Entender as fronteiras como margens requer, também, repensar a anarquia e o estado de natureza em outros termos. Rousseau (1978), por exemplo, entende o estado de natureza nos termos de Locke (1983), mas, ao contrário deste e de Hobbes (1983), concebe a propriedade como fator que instaura a desigualdade entre os homens. Assim, a propriedade expressa na tomada da terra, projetaria do interior para o exterior a desigualdade doméstica produzindo uma outra clivagem político-espacial transversal à territorialização orientada por fronteiras impermeáveis como requerida pelo Estado. Pois, se a tomada de terra na acepção schmittiana e da leitura hobbesiana / lockeana produziu incivilizados ao Sul e civilizados ao Norte, a leitura da tomada de terra na perspectiva rousseauniana produz injustiçados no Sul e no Norte. Desta forma, um novo registro por meio do qual poderíamos ressignificar o entendimento da anarquia e do estado de natureza nas relações internacionais teria que considerar, independentemente das diferentes clivagens produzidas pela espacialidade territorial estatal, aquela resultante da própria desigualdade que a estatalidade engendra no nível global de sua manifestação.

Não abdicar da anarquia e do estado de natureza ou interpretá-los a partir de novos registros na compreensão do internacional requer, antes de tudo, não apenas ler o mundo a partir das docas da cidade indiana de Calicute (BOUCHERON, 2015), 
mas um novo entendimento da ideia de fronteira. Na percepção dos Estados ela constitui limites que separam duas regiões sujeitas a domínios políticos diferentes, mas a plausibilidade de tal raciocínio depende da aceitação de a sociedade nele subsumir. Na medida em que a fronteira também é um entre dois, ela comunica e articula em suas margens mundos distintos e nos diz quem as atravessa oriundo de uma das margens. Assim, podemos ver através das margens e construir um novo relato acerca de nós mesmos e de nosso lugar no mundo.

Conferir um novo sentido à ideia de fronteira provoca, assim, um deslocamento semântico no entendimento da anarquia e do estado de natureza, já que provoca uma ruptura na percepção do internacional como territorializações fechadas, pressuposto sem o qual as próprias ideias de anarquia e de estado de natureza em suas acepções tradicionais perderiam sua capacidade interpretativa. Romper-se-ia, também, com a dicotomia ordem doméstica e ordem externa, o que conduziria, necessariamente, ao não entendimento do Estado como contendor da sociedade. A partir das margens em que vemos o outro que também nos olha, construir uma nova narrativa que demarcaria um novo lugar, uma nova espacialidade capaz de conferir novos significados às interações de injustiçados em nível global.

Proceder dessa maneira pode parecer, aos olhos daqueles que advogam uma produção teórica genuinamente do Sul, uma heresia. Mas, mesmo que possamos produzir teorias genuinamente do Sul, a Ciência moderna em que somos socializados na academia é um empreendimento historicamente demarcado: nasceu e se desenvolveu no Ocidente. Queiramos ou não, integramos um sistema de pensamento que deve se abrir ao entendimento e reconhecimento de outros saberes, mas que não opera nos mesmos termos desses outros saberes. Nosso lugar de discurso é o da ciência ocidental e o que podemos fazer é subvertê-la no sentido de recorrer às suas categorias, mas lendo-as em um registro diferente daquele que convencionalmente é feito a partir do Norte. Em outras palavras, à maneira das etnias que aqui existiam quando dos Descobrimentos, empregá-las a serviço de regras, costumes ou conviç̧ões estranhas ao seu aparato interpretativo e às relações de poder que engendram e sustentam a estruturação desigual do sistema ou da sociedade internacional. 


\section{Referências}

AGNEW, John. Geopolítica: una re-visión de la política mundial. Recife: Editor digital: Titivillus, 1998.

ARON, Raymond. Paz e Guerra entre as Nações. Brasília: Editora Universidade de Brasília, Instituto de Pesquisa de Relações Internacionais; São Paulo: Imprensa Oficial do Estado de São Paulo, 2002.

BARRETO, Luís Felipe. Os Descobrimentos e a ordem do saber: uma análise sóciocultural. Lisboa: Gradiva, 1987.

BOUCHERON, Patrick. La época de los "grandes descubrimientos". In: SASSEN, Saskia et al. El Atlas de la globalización: todas las claves del proceso que está cambiando el mundo. Buenos Aires: Capital Intelectual, 2015.

DE CERTAU, Michel. Artes de Fazer: a invenção do cotidiano. $3^{a}$ ed. Petrópolis: Vozes, 1998. Nova edição, estabelecida e apresentada por Luce Giard.

DURAND, Marie-Françoise, LÉVY, Jacques e RETAILLÉ, Denis. Le Monde: Espaces et Systèmes. $2^{\mathrm{a}}$ ed. Paris: Fondation Nationale des Sciences Politiques; Dalloz, 1993.

HARTMANN-PETERSEN, P. e PIGFORD, J. N. Dicionário de Ciência. Lisboa: Publicações Dom Quixote, 1991.

HÉBERT, John R. The 1562 Map of America by Diego Gutiérrez. Disponível em The Library of Congress: https://memory.loc.gov/intldl/eshtml/es-1/es-1-2-5-1.html. Acessado em Maio de 2012.

HOBBES, Thomas. Leviatã ou, Matéria, forma e poder de um Estado eclesiástico e civil. São Paulo: Nova Cultural, 1983. (Os Pensadores).

KRASNER, Stephen D. La Soberanía perdurable. In: Colombia Internacional, № 53 , Septiembre - Diciembre $2001 . \quad$ Disponível em: http://colombiainternacional.uniandes.edu.co/. Acesso em 10 de setembro de 2019.

LOCKE, John. Segundo Tratado sobre o Governo. In: Locke. $3^{a}$ ed. São Paulo: Abril Cultural, 1983. Coleção Os Pensadores.

MORAIS, Carlos Blanco de e COUTINHO, Luís Pereira. (Orgs.) Carl Schmitt Revisitado. Lisboa: Instituto de Ciências Jurídico-Políticas / Universidade de Lisboa, Março de 2014

MORGENTHAU, Hans J. A Política entre as Nações: a luta pelo poder e pela paz. São Paulo: Imprensa Oficial do estado de São Paulo; Editora Universidade de Brasília; Instituto de Pesquisa de Relações Internacionais, 2003. 
RATZEL, Friedrich. Géographie Politique. Paris: Ed. Économica, 1988.

ROUSSEAU, Jean-Jacques. Rousseau: Do contrato social; Ensaio sobre a origem das línguas; Discurso sobre a origem e os fundamentos da desigualdade entre os homens; Discurso sobre as ciências e as artes. $2^{a}$ ed. São Paulo: Abril Cultural, 1978. (Os pensadores).

SANTOS Filho, Onofre. Racionalidade cientifica em Minas Gerais no século XIX. Dissertação de Mestrado em Sociologia, Universidade Federal de Minas Gerais, 1993.

SCHMITT, Carl. O Conceito do Político / Teoria do Partisan. Belo Horizonte: Del Rey, 2008.

SCHMITT, Carl. O nomos da Terra: no direito das gentes do jus publicum europæum. Rio de Janeiro: Contraponto: Ed. Da PUC-Rio, 2014.

TILLY, Charles. Coerção, Capital e Estados Europeus. São Paulo: Editora da Universidade de São Paulo, 1996.

VATTEL, Emer de. O Direito das Gentes. Brasília: Editora da UnB; Instituto de Pesquisa de Relações Internacionais, 2004.

VILLACAÑAS, José Luis. Poder y Conflicto: Ensayos sobre Carl Schmitt. Madrid: Editorial Biblioteca Nueva, 2008.

WALTZ, Kenneth. Teoria das relações Internacionais. Lisboa: Gradiva, 2002.

ZIENTARA, Benedikt. Fronteira. In: Enciclopédia Einaudi. Lisboa: Imprensa Nacional - Casa da Moeda, 1989. Volume 14: Estado-Guerra. 